\title{
Enhancing Teacher Preparation and Improving Faculty Teaching Skills: Lessons Learned from Implementing "Science That Matters" a Standards Based Interdisciplinary Science Course Sequence
}

\author{
Robert Potter $^{1,3}$ and Gerry Meisels ${ }^{2}$
}

\begin{abstract}
In a highly collaborative process we developed an introductory science course sequence to improve science literacy especially among future elementary and middle school education majors. The materials and course features were designed using the results of research on teaching and learning to provide a rigorous, relevant and engaging, standard based science experience. More than ten years of combined planning, development, implementation and assessment of this college science course sequence for nonmajors/future teachers has provided significant insights and success in achieving our goal. This paper describes the history and iterative nature of our ongoing improvements, changes in faculty instructional practice, strategies used to overcome student resistance, significant student learning outcomes, support structures for faculty, and the essential and informative role of assessment in improving the outcomes. Our experience with diverse institutions, students and faculty provides the basis for the lessons we have learned and should be of help to others involved in advancing science education.
\end{abstract}

KEY WORDS: engaged teaching; faculty development; interdisciplinary science; systemic change; elementary school teacher science education.

\section{INTRODUCTION}

Boundless enthusiasm and some naiveté can carry you well into a problem before the complexities and magnitude of the challenge are fully appreciated. Improving science education has proven to be such a daunting, yet exciting challenge. Our history in science education spans 10 years, two NSF grants, more than 70 faculty partners from diverse institutions, and over 600 students. We hope that sharing our experiences, including approaches taken, materials devel-

\footnotetext{
${ }^{1}$ Department of Chemistry and the Coalition for Science Literacy, University of South Florida, 4202 Fowler Ave/SCA400, Tampa, Florida 33620.

${ }^{2}$ Coalition for Science Literacy and Department of Chemistry, University of South Florida, Florida.

${ }^{3}$ To whom correspondence should be addressed; e-mail: potter@cas.usf.edu.
}

oped, and, most importantly, outcomes and lessons learned, will be helpful in facilitating advances in science education at other institutions.

"Most ideas about teaching are not new, but not everyone knows the old ideas" Euclid 300 B.C. Our experience confirms that even those who do know can benefit from frequent reminders. It is with this understanding that we present our "Lessons Learned" and explore them in the context of our history with science education reform.

\section{Lessons Learned}

1. Engaging students in learning is challenging and requires new skills for both faculty and students.

2. Developing the new skills takes time and practice but pays dividends. 
3. Expect student resistance and consistently and frequently communicate the rationale for what you do and high expectations for learning.

4. Students require significant guidance and practice for active learning, collaboration and reflective activities to be effective.

5. Designing flexibility into the grading process accommodates student intellectual development over the term and enhances student satisfaction, motivation and effort.

6. Long-term support of peers, chairs, and deans is important for successful faculty involvement and requires ongoing communication of the outcomes and value of the effort.

7. Working collaboratively with teacher preparation program administrators, faculty and advisors is essential to promoting more effective science for pre-service teachers.

8. Evaluating improves your program; work with a professional to improve your evaluation.

\section{DEVELOPMENT OF "SCIENCE THAT MATTERS" (STM)}

\section{Rationale}

Science literacy and civic engagement are not simply achieved goals (Palady, 2002). Yet they are clearly essential for effective decision-making in today's complex, technology driven society. Science encompasses a broad range of disciplines and thus any approach desiring to achieve science literacy with clear connections of the science to civic responsibilities must explicitly and consistently focus on both features as the important outcomes.

The National Science Education Standards (NSES, NRC, 1996) and Project 2061 (AAAS, 1993) along with state and local standards have provided important guidance for the content of courses and curricula that meet the needs of broad science literacy. These guidelines also emphasize the need to focus on major science concepts, real world applications of scientific information and inquiry to effectively promote learning. Therefore, coupling standards-based science with applications from important and timely civics based issues is an approach we have pursued to develop both science literacy and thoughtful civic engagement.

\section{History}

"Science That Matters" was developed as the result of a 1995 workshop "Meeting the Challenges of General Science and Mathematics Education" arranged by the Coalition for Science Literacy (CSL) at The University of South Florida (USF) for 130 mathematicians and scientists from the Tampa Bay region. A consensus on the need for change in science evolved into the "Science That Matters" project while at that time consensus for changes in mathematics remained elusive. A team working through the CSL secured grants from the National Science Foundation, (DUE 9752498) the Florida Department of Education, and the Southwest Florida Water Management District to produce a set of college level science modules based on advances in teaching and learning (Grasha, 1996; Griffin, 1995, Grosslight et al., 1991; Kolb, 1984; NRC, 1997, 1999a, 1999b, 2003; Sarasin, 1998). Development of course materials was a collaborative process involving more than 60 university, college and community college faculty from the Tampa Bay region. The National Science Foundation (DUE-0231179) and the Coalition currently support ongoing developments and implementation on a broader scale.

\section{Course Description}

"Science That Matters" is a two-semester course series for non-science majors/future teachers. Courses focus on four to five important topics per semester each addressed in a two-to-four week long module. Individual modules deal with complex subjects such as global warming and water management that require specialized knowledge in more than one scientific sub-discipline or focus on major concepts that can be illustrated in several sub-disciplines, such as energy conversion. The modules are designed to engage students through subjects and questions relevant to their daily lives. The topics connect scientific knowledge to public decision-making and policy development (Table I) with the goal of producing more scientifically literate and engaged citizens. As such, this course promotes the goals of the national $S E N C E R$ project (Science Education for Civic Engagement and Responsibilities). Our team has benefited greatly from the support and professional development SENCER has provided.

The goals of STM are multiple and focus on both faculty and students. 
Table I. Example Topics and Public Policy Relationships

\begin{tabular}{|c|c|}
\hline $\begin{array}{l}\text { Selected scientific } \\
\text { principles and topics }\end{array}$ & $\begin{array}{l}\text { Relationships to public } \\
\text { issues and policy }\end{array}$ \\
\hline Nature of science & $\begin{array}{l}\text { Need to understand what science is, } \\
\text { what it isn't and how it works. Issues } \\
\text { of scientific responsibility }\end{array}$ \\
\hline Evolution & $\begin{array}{l}\text { Understanding of nature, the } \\
\text { relatedness among organisms and } \\
\text { how things change over time. } \\
\text { Antibiotic resistance }\end{array}$ \\
\hline $\begin{array}{l}\text { Climate, weather and } \\
\text { the hydrologic } \\
\text { cycle }\end{array}$ & $\begin{array}{l}\text { Global climate and weather } \\
\text { patterns/change. Water use, } \\
\text { availability, quality and sustainability. } \\
\text { Human impacts }\end{array}$ \\
\hline Biodiversity & $\begin{array}{l}\text { Impact of humans on the environment, } \\
\text { issues of resource management. } \\
\text { Sustainability of habitats. Biodiversity } \\
\text { as a resource }\end{array}$ \\
\hline $\begin{array}{l}\text { Energy, force and } \\
\text { motion }\end{array}$ & $\begin{array}{l}\text { Fuel consumption, who uses it and how } \\
\text { much. Renewable vs. non-renewable } \\
\text { sources of energy, where do we get it } \\
\text { and where does it go. Tires, airbags } \\
\text { and automobile safety, how safe is } \\
\text { safe? }\end{array}$ \\
\hline Genetic engineering & $\begin{array}{l}\text { Genetically modified foods, benefits and } \\
\text { safety issues. Human Genome } \\
\text { Project, use of scientific information } \\
\text { in fields of medicine and business }\end{array}$ \\
\hline
\end{tabular}

\section{Goals of "Science That Matters"}

1. Create a relevant, interesting, interdisciplinary basic science course based on the National Science Education Standards.

2. Develop students' positive attitude toward science and an understanding of its role in society.

3. Improve students' science literacy.

4. Emphasize experiential learning and inquiry.

5. Improve students' critical thinking/problem solving and ability to apply knowledge.

6. Encourage faculty to be reflective teachers and to work together to examine and improve their own instructional practices.

7. Prepare future elementary teachers with the necessary understanding of science to effectively teach science.

The student centered outcomes of these goals are addressed in a number of ways as illustrated in Table II.

\section{Course Offerings and Structure}

"Science That Matters" was first piloted at USF in the fall of 1999 and either "Science That Matters"
Table II. Intended Course Outcomes and Approaches

\begin{tabular}{|c|c|c|}
\hline Outcome & & Notes on approaches \\
\hline Scientific literacy & Yes & $\begin{array}{l}\text { Focus on major science concepts } \\
\text { and processes of science as } \\
\text { described in the National } \\
\text { Science Education Standards }\end{array}$ \\
\hline Critical thinking & Yes & $\begin{array}{l}\text { Course activities and } \\
\text { examinations emphasize } \\
\text { critical thinking/problem } \\
\text { solving and application of } \\
\text { information; require valid } \\
\text { support for statements or } \\
\text { positions }\end{array}$ \\
\hline Improved writing & Yes & $\begin{array}{l}\text { All journals, assignments and } \\
\text { tests require written answers. } \\
\text { Many assignments use } \\
\text { feedback and iteration as } \\
\text { opportunities for improvement }\end{array}$ \\
\hline Civic education & Yes & $\begin{array}{l}\text { Promote the need for } \\
\text { understanding science among } \\
\text { citizens by connecting science } \\
\text { to topics and issues relevant to } \\
\text { today's society-impact of } \\
\text { science on society }\end{array}$ \\
\hline Ethical reasoning & Yes & $\begin{array}{l}\text { Through discussion of } \\
\text { responsibilities of scientists and } \\
\text { topics such as genetic } \\
\text { engineering, use of genetic } \\
\text { information, water and other } \\
\text { resource use }\end{array}$ \\
\hline $\begin{array}{c}\text { Quantitative } \\
\text { reasoning }\end{array}$ & Yes & $\begin{array}{l}\text { Calculations and manipulation of } \\
\text { data used in making } \\
\text { predictions and evaluations }\end{array}$ \\
\hline $\begin{array}{l}\text { Understanding of } \\
\text { public policy }\end{array}$ & Yes & $\begin{array}{l}\text { Relationships between issues } \\
\text { such as biodiversity, global } \\
\text { warming and water resources } \\
\text { and economic/industrial } \\
\text { development }\end{array}$ \\
\hline Global awareness & Yes & $\begin{array}{l}\text { Units on biodiversity and water } \\
\text { management undertaken from } \\
\text { both local and global } \\
\text { perspective. Given } \\
\text { environmental sensitivity of } \\
\text { Florida (especially impact of } \\
\text { habitat destruction, exotic } \\
\text { species invasions and water } \\
\text { use) these are locally important } \\
\text { topics that can be expanded to } \\
\text { global scale }\end{array}$ \\
\hline
\end{tabular}

I or II has been offered each semester since. Section size has ranged from $25-38$ students ( 25 or less is easier to manage and more effective). Beginning in Fall 2001 multiple sections have been offered as part of a new College of Arts and Science linked course learning community with one or more sections set aside especially for pre-elementary education majors. Similar courses based on this model have been initiated at Manatee Community College in Florida 
and at Fairmont State University in West Virginia with a generally smaller class size (15-25). Others experimenting with this approach are St. Petersburg College and Hillsborough Community College, both in Florida, and Middlesex Community College in Massachusetts. A total of 16 faculty have now taught this course at least once and many are serving as coaches for newer instructors.

Course formats vary among institutions; however 75 min twice per week or one hundred twenty minutes twice per week have been the most successful. The longer format provides more opportunities to break up the instruction with summaries, some direct instruction and opportunities for multiple activities. The Fairmont and the Manatee groups have accommodated the longer time frame by associating the course with a laboratory and found this format to be particularly successful. In all cases, classrooms with internet connections and projection equipment enable rapid access to additional information. Tables or benches are a must for group work, facilitating the many hands-on collaborative activities.

\section{Evaluation Approach}

Multiple sources of information have been used to inform the ongoing development of the STM courses. These include student surveys, student focus groups, student written responses, faculty reflective written responses and classroom observations. All have been approved by the University Institutional Review Board with all responses taken anonymously. Surveys based on the more extensive Student Assessment of Learning Gains (SALG) http:// www.wcer.wisc.edu/salgains/instructor/ have been used at all sites to provide student feedback to specific instructors and the program on class atmosphere, course logistics, the value of various instructional strategies and information concerning students' perceptions of their attainment of STM goals. A presurvey is used to largely obtain student background information, An example of the both pre and post surveys can be found at the Coalition for Science Literacy web site (http://web.usf.edu/ sl/CSL/) under STM. Focus groups have provided a very rich source of information since the professional interviewers are able to ask students to explain their answers. For logistical reasons focus groups have thus far been done only at the USF site. Typically our evaluation expert and an education graduate student facilitate the discussion with 10-12 randomly selected students from each section of about 30 . Students are asked to respond to a set of questions (see below) and the responses may be followed up by additional questions from the facilitators asking the students to explain or elaborate on what was said. Students not involved in the focus group are asked to respond in writing to the same set of questions.

Focus group questions:

1. Give an example of how "Science That Matters" has impacted your ability to think critically and use information to solve problems and answer questions.

2. Give an example of how "Science That Matters" has influenced your understanding of science in the news and science that affects your everyday life.

3. In what ways have you been able to apply problem-solving approaches learned in "Science That Matters" to your other coursework?

4. In what ways has "Science That Matters" increased your understanding about the processes of science?

5. Would you recommend this course to other students? Why or why not?

Faculty teaching STM are asked to respond in writing, at the end of the semester, to the following set of reflective questions:

1. Has STM affected how you view teaching and learning? Please explain

2. How has this or might this effect your teaching in other courses? Please explain

3. What were the most enjoyable aspects of teaching this course?

4. What were some of the problems encountered?

5. What would make your job as instructor in STM easier?

6. What suggestions would you offer to future instructors of STM?

Summaries from the evaluative information are returned to instructors along with the specific information from their sections.

Classroom observation by trained professionals is an excellent source of information for individual instructors. While initially somewhat intimidating, both new and experienced instructors have found the feedback valuable in helping them improve the orchestration of classroom activities. 


\section{Support Materials}

Volumes I and II of "Science That Matters", containing six modules each with readings, are available in student versions from Kendall/Hunt Publishers Inc., (http: //www.kendallhunt.com/). Additional information about the modules and support materials for instructors (background information, instructions and rationale for activities, answers for questions and assessments) can be obtained from the Coalition for Science Literacy at USF, (http://web.usf.edu/ sl/CSL). We continue to adjust and refine the materials with ongoing feedback from our creative faculty colleagues at the partner sites through support from NSF (DUE-0231179) and the CSL. Fairmont State University has taken advantage of the inherent flexibility of the modular approach and web-based instructional resources to begin experimenting with an exciting web based format to support instruction that can be modified more readily than the printed versions.

\section{LESSONS LEARNED: A CLOSER LOOK}

Now let us examine in more depth the lessons we have learned along our way to implementing "Science That Matters."

\section{Lesson 1: Engaging Students in Learning is Challenging and Requires New Skills for both Faculty and Students}

"If you keep doing what you've always done, you'll keep getting what you've always got."Anonymous. To help faculty improve classroom outcomes and move away from lecture, we took the approach of writing lesson plans based largely on active learning and supplemented the lesson plans with professional development. Initial workshops focused on the need for change and the rationale for active learning. While an important beginning, it takes time for faculty to master the very different skills required of the active learning or engaged classroom (Designed Instruction, 2003; Druit and Treagust, 2003; Grasha, 1996; NRC, 1997).

STM faculty must first and foremost be focused on the major learning goals for each module and understand how these fit with daily objectives for student learning (Klionsky, 2003; NRC, 2003). They must then ensure that students have the opportunities to achieve these outcomes beginning in the classroom and followed with additional reflective ac- tivities as homework or as longer term projects. This requires that faculty be able to apply what may be a number of new skills. They must be able to orchestrate and facilitate student collaborative work (BSCS, 1999; Holloway, 2003; Tanner et al., 2003), use effective questioning strategies (Marbach-Ad and Sokolove, 2000; Penick et al., 1996), know when to provide direct instruction and how much to provide (Druger, 2002), how to moderate class discussions and, perhaps most important of all, how to effectively debrief the day's events, bringing clear focus to the expected learning outcomes (NRC, 1999b). Debriefing should be followed with instructions for the students on relevant out-of-class assignments, again complete with purpose. Failure to successfully negotiate these tasks leads to frustration on the part of students and faculty. Faculty can become dissatisfied with student performance and students are often confused about what is important and how to study. Clarity of purpose and clarity in assignment directions are key to course success and will be addressed in more detail below in Lesson 3.

The benefits for faculty, of being involved even for only a single semester, are apparent in their comments on our instructor reflections. They see the energy and excitement that can be generated in the engaged classroom and this seems to change their views about teaching. This is clearly illustrated in the representative comments taken from this past year's instructor reflections when asked the following question: Has STM affected how you view teaching and learning? Please explain.

1. "I saw how the activities and group work help the students learn the course material. In courses that I have taught in the past, my teaching style has been primarily lecture. In the STM course, I lectured much less."

2. "I could see how well my students in STM responded to the activities-based approach, with very small amounts of lecture or presentation around the edges. Over and over they commented on how fast a (2-hr) class period went by. They also truly appreciated the real-world applications."

3. "STM has reinforced my ideas about the importance of laboratory-type (and other) activities for the overall education of the student. By bringing the activities into the main classroom and pairing it with a brief lecture before or after the activity, I think that the 
hands-on learning is more immediate and that this is beneficial."

4. "STM has forever altered the way that I will teach a course. I will never design a classic lecture course again."

5. "Yes. It has forced a re-evaluation of the way content drives curriculum. By looking at concepts first and building from there the curriculum is driven by concepts not content."

A second challenge and benefit for faculty is the interdisciplinary nature of the courses. Traditionally, most faculty have a strong content background in a single area of expertise, such as chemistry, and often may have had little or no exposure to other areas such as biology. Alternatively, learning in other areas of science may have been so far in the past that faculty are no longer familiar with them. We have addressed this in two ways. Lesson plans for each module incorporate additional background information for the instructor, including useful websites for both faculty and students. Perhaps more helpful has been the teaming of physical scientists with life scientists. The Fairmont State University group has been particularly successful in working as a team to prepare for class and to debrief and modify the outcomes of each week's instruction. While faculty members, each a specialist in biology, chemistry, earth science or physics, teach their own sections, they work as a team to help each other in areas where expertise may not be as great. Typically individual faculty members take the lead in developing mini-lecture materials/presentations for a topic in which they have strong expertise. These are made available to the whole group in support of the module activities. Importantly, the full team meets once a week to prepare for the upcoming week and to discuss what worked well in the classroom, what didn't and how to improve. This approach has also been adopted at USF and has been very helpful and intellectually stimulating for both new and experienced instructors.

A significant benefit of teaching interdisciplinary science is the considerable potential to promote understanding across disciplines benefiting both faculty and students. This was an unexpected but very pleasant outcome given the need for today's scientists (and those of tomorrow) to more often work as interdisciplinary teams and to promote this kind of thinking and training among their students (Boyer, 1998; NRC, 1997). This outcome is evident in the sample comments below from instructors when asked the following question: How might STM affect your teaching in other courses? Please explain:

1. "I will be incorporating some activities into the other courses I teach. As a result, I will be doing less lecturing in my other classes."

2. "Thanks to what I have learned in the biology modules in STM, we incorporated additional biochemistry topics on nucleic acids and H-bonding into our majors-level introductory chemistry course this fall."

3. "The more I teach STM, the more I have a basis from which to read scientific papers and review articles in other areas (e.g., Science, Nature, Discover, Scientific American, Science News) and the more I see what is being done and what questions are being asked, the more I can tie my chemistry classes into other disciplines in a natural way."

Students are also challenged by the STM approach which requires many new skills not often used in the more prevalent lecture-based approaches. Learning as a collaborative process, critical thinking/writing, evaluation of arguments and validation of source credibility are all valuable new skills and abilities cultivated in STM. Since most activities are done, at least in part, as teams, students need to develop skills for collaborative work. In addition critical thinking and writing are a part of most assignments. In our experience, few students coming out of high school seem to have mastered these skills and thus require specific instruction and frameworks to be successful (see Lesson 4). Student responses on surveys (Table III) suggest that group work/activities are valuable and that students have improved their critical thinking and evaluation skills.

Student's written comments and information from focus group responses also indicate that students see improvements in the way they think and approach problem solving. A few examples of student comments are:

1. Science that matters has impacted my ability to think critically and use information to solve problems and answer questions. It has made me see other details that I normally would not have seen. It has made me think more in depth about something. When a problem is given to me, I look at the big picture. I go through different steps to try and solve the problem. The scientific method and process could help in this a little. I try to eliminate the solutions that would not work and then try to come up with something better. 
Table III. Sample Student Survey Results-“Science That Matters"

\begin{tabular}{|c|c|c|c|c|c|c|}
\hline & \multicolumn{6}{|c|}{ (Percentage of students) } \\
\hline & SD & D & MD & MA & A & SA \\
\hline \multicolumn{7}{|l|}{ Science content and attitude } \\
\hline $\begin{array}{l}\text { I am able to be } \\
\text { analytical and logical } \\
\text { in approaching and } \\
\text { analyzing problems }\end{array}$ & & & 3.3 & 31. & 50.8 & 14.8 \\
\hline $\begin{array}{l}\text { I am able to critically } \\
\text { evaluate scientific } \\
\text { findings. }\end{array}$ & & & 1.6 & 37.7 & 49.2 & 11.5 \\
\hline \multicolumn{7}{|l|}{ Course characteristics } \\
\hline $\begin{array}{l}\text { I learned something of } \\
\text { value in this course }\end{array}$ & & 1.6 & 3.3 & 21.4 & 50.9 & 24.6 \\
\hline $\begin{array}{l}\text { Class discussion was } \\
\text { encouraged }\end{array}$ & & & & 5.0 & 39.3 & 57.4 \\
\hline $\begin{array}{l}\text { In-class activities and } \\
\text { exercises increased } \\
\text { my understanding of } \\
\text { the subject }\end{array}$ & 1.6 & 1.6 & & 18.0 & 34.4 & 44.3 \\
\hline $\begin{array}{l}\text { The homework } \\
\text { assignments were } \\
\text { meaningful and } \\
\text { promoted } \\
\text { understanding of the } \\
\text { course material }\end{array}$ & 1.6 & 3.2 & 8.2 & 29.5 & 37.7 & 14.8 \\
\hline $\begin{array}{l}\text { The tests covered what } \\
\text { was emphasized in } \\
\text { class \& in the } \\
\text { readings }\end{array}$ & & 1.6 & 4.9 & 18.0 & 37.7 & 37.7 \\
\hline
\end{tabular}

Note. 61 Total Students-2 Sections USF. SD = Strongly disagree; $\mathrm{D}=$ Disagree; $\mathrm{MD}=$ Moderately disagree; $\mathrm{MA}=$ Moderately agree; $\mathrm{A}=$ Agree; $\mathrm{SA}=$ Strongly agree.

2. Science that matters has impacted my ability to think critically and use information to solve problems and answer questions in a good way. I have learned how to use the information and break it down into smaller things that are easier to understand. Once I can grasp an understanding I can answer the questions.

3. In science that matters we take broader information and then break it down piece by piece to understand all of the steps of what we are discussing so when I'm not in class, I'm able to process information better and think about the important issues that could have an impact on my life.

4. Well, now that I have enjoyed this class with 2 different profs. I see that I have learned new ways to visualize things. Like before, I would usually just skip over something if I didn't understand it. But now, if I don't get the answer right away I look for it longer.

5. Through this class I have learned that when I am given any piece of information whether it is science related or not, I should look deeper into the information than what is just given to me at face value. Information can be misunderstood and through this class it taught me that you must think about the information before making that step with using the information

\section{Lesson 2: Developing the New Skills Takes Time and Practice but Pays Dividends}

"Practice is the best of all instructors."-Publilius Syrus. To this we would add that a good coach is also invaluable. Experienced colleagues or even those who will just listen and offer advice are valuable in providing support that helps new or even experienced instructors work through new instructional approaches and challenging classroom situations. A reflective attitude toward teaching (NRC, 1997, 2003) with a willingness to try new things and a desire to continue improving the outcomes are important qualities for effective STM instructors. High quality teaching materials also smooth the transition from direct or lecture techniques to the activities-based engaged classroom approach. The less instructors must think about what will happen in the classroom the more they are able to focus on seeing that this leads to effective student opportunity to achieve the day's intended outcomes. Good materials can thus help shift the focus from "what will I teach" and "how will I teach it" to "what are the outcomes of what I teach" and "what must I do in the classroom to achieve this." Our experience says faculty new to active learning or to active learning on a specific topic benefit from well-designed materials. However, once faculty understand the mechanics of this approach and the key elements for successful learning, we find they often modify the materials in creative ways to better suit national or local current events. The aspect of currency improves students' interest and reinforces the role of science in their daily lives (Leamnson, 2000; Strong et al., 2003).

Some examples of the dividends for faculty are listed in the comments below:

1. "STM has taught me the value and utility of interacting with students and getting them to interact. Many have told me that group discussion helps improve their understanding of the material by forcing them to interact and listen to the other group members. A purely lecture course could never accomplish these things." 
Table IV. "Science That Matters" Sample Student Survey Data*

\begin{tabular}{|c|c|c|c|c|c|c|}
\hline & \multicolumn{6}{|c|}{ (Percentage of students) } \\
\hline & SD & $\mathrm{D}$ & MD & MA & A & SA \\
\hline \multicolumn{7}{|l|}{ Science content and attitude } \\
\hline $\begin{array}{l}\text { This course increased } \\
\text { my interest in Science }\end{array}$ & & 6.0 & 13.0 & 31.0 & 46.0 & \\
\hline $\begin{array}{l}\text { Scientific ideas are } \\
\text { something I can } \\
\text { understand and use }\end{array}$ & & & 3.3 & 26.0 & 59.0 & 13.0 \\
\hline $\begin{array}{l}\text { I am able to understand } \\
\text { the implications of } \\
\text { scientific findings to } \\
\text { public issues }\end{array}$ & & & 3.3 & 29.5 & 50.9 & 16.4 \\
\hline $\begin{array}{l}\text { I am able to use } \\
\text { scientific evidence to } \\
\text { make an informed } \\
\text { choice on public } \\
\text { policy issues }\end{array}$ & & & 1.6 & 32.8 & 54.1 & 13.2 \\
\hline
\end{tabular}

Note. 61 Total Students-2 Sections USF. SD = Strongly disagree $; \mathrm{D}=$ Disagree $; \mathrm{MD}=$ Moderately disagree $; \mathrm{MA}=$ Moderately agree; $\mathrm{A}=$ Agree; $\mathrm{SA}=$ Strongly agree.

2. "I think the re-evaluation of the curriculum in all my courses will be the result of this. I am developing a rubric for what content I will retain or delete."

3. "I am thoroughly enjoying the opportunity to interact with non-science majors in a course that they perceive as interesting and fun."

4. "Trying new approaches to active learning. At first I was a bit intimidated that something would not go over very well. Although this has happened on various occasions I soon became more experimental in my approach. Some things work and other do not; one has to keep searching for ways to grab students' attention."

5. "Watching students engage in previously avoided material \& use "scientific" approaches to problem solving."

Dividends for students who get involved are many. Surveys of students (Table IV) indicate an increased interest in science and ability to understand and apply scientific information to public policy decisions.

The survey data is supported by written student comments and by focus group information as indicated below.

1. Taking Science that Matters has made me wonder more about how things are made and how things work. Before, I never thought much about the reason things were how the were. For example, one day as I was driving home from school I saw a rainbow in the sky. I wondered why rainbows were always in the same form \& same colors. I thought abut what we had learned in class \& found a credible web site to help me find my answer

2. I look at things differently now. Like I really focus on the sky and what the clouds mean, just have a wider outlook on thing. Wonder how they work too

3. Now that I see scientific news or scientific things in everyday life I always have something so say about it because through this class you learn the deeper meaning of what science really is and how it affects your life every single day and through this class I realized that.

\section{Sample Focus Group Analysis}

Related to "Science That Matters" goals, students in both the focus group and the written response group indicated that the course material had helped them understand the science-related news in television news broadcasts and newspapers. Most students agreed that instructors had worked hard to achieve the goal of increasing awareness regarding the applicability of science to the world in which they live. Several students also indicated that their favorite assignments had been those that required them to use current news items. Specific examples by students generally included more comfortable usage and comprehension of scientific vocabulary in areas such as genetics, physics and astronomy. One student in the focus group said, "I feel smart when I read the newspaper now. Things that I would have just skipped over before are interesting to read now because I have an understanding of the topic." Similar sentiments were echoed in the written responses. Furthermore, more than half of the students indicated that there had been a notable emphasis on problem solving in the course design. As soon as this topic was raised in the focus group, a student reacted by stating, "The tests are very different from what you expect in science classes and you have to use what you know to solve problems." Likewise, many of the written responses mentioned ways the course helped them "use information, not just memorize it."

Clearly one of the major instructional successes has been having students analyze news articles 
related to science. The standard assignment instruction format is:

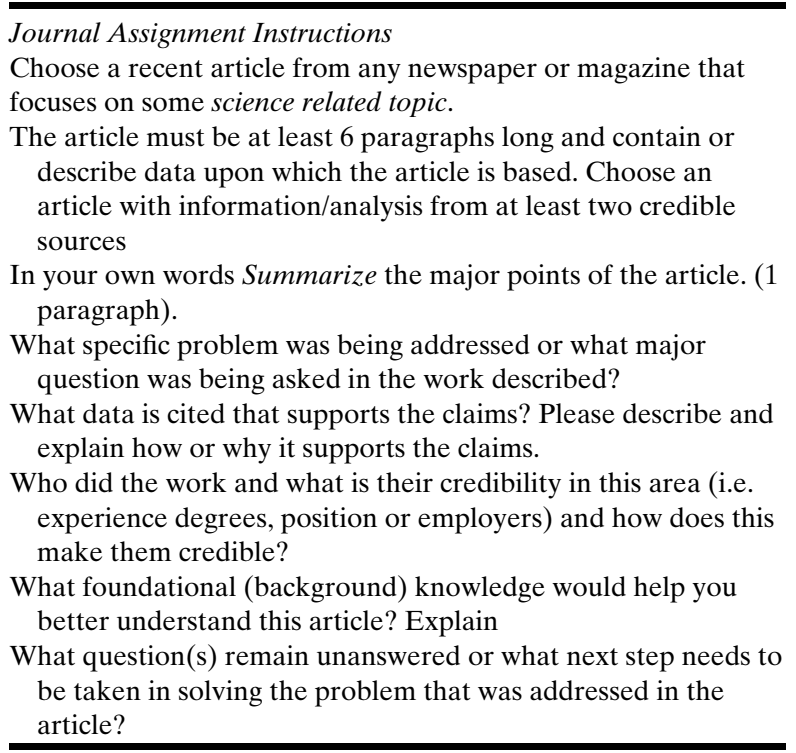

The dividends for this activity are the highly positive student responses to these assignments and the learning outcomes. Students overwhelmingly refer to the journal articles as an example in focus groups and in their written comments when asked has the course increased their understanding of how science relates to their everyday lives (see below). They also refer to these assignments when discussing how the course has helped them improve their critical thinking skills.

Representative written responses to: Give an example of how "Science That Matters" has influenced your understanding of science in the news and science that affects your everyday life

1. "Science that matters has influenced my understanding of science in the news and science that affects everyday life. I know more about science and ideas that are talked about in the news. I also know more about why things occur and happen in nature and what affects they have."

2. "Most of the topics in science that matters has trigged some response to events I encounter through mass media. Particularly the topics in the STMII have pertained to areas of interest in today's society. It has been brought a better understanding to what was correct in class to what is presented in the news and in my own health and well being. That matters!"
3. "STM has affected the way I understand the news now. I have some science background as far as technical science and all the terms and names. STM gave me the opportunity to apply all my knowledge into everyday things. Simple new articles are easier to put into perspective."

4. "This class affected my life in a positive way because I understand a few things that I already knew of but I learned more about them. We did projects and I've never been in a group w/other people in college. I did that in high school. I enjoyed this class, overall \& I hope that my grade would probably reflect my understanding."

5. "STM has given me some insight on how science in the new is given. It taught me to look at the credibility of the source from were the information came not just saying that looks like good information and using it."

Several characteristics of the journal assignments are likely responsible for the impact and are worth stressing since they have relevance to developing effective learning opportunities generally. First the students have a choice over what article they choose although guide lines are provided. Student choice seems to improve motivation (Leamnson, 2000; Strong et al., 2003). Even if the general topic is limited to an article related to the current classroom unit or to one of several articles selected by the instructor, the students still seem to enjoy the activity more than analysis of a single instructor-chosen article. Allowing student choices is beneficial because it improves engagement. However, we have found that the instructors again must be clear about the expected outcome and provide students sufficient direction so that outcome can be achieved. The second characteristic of the journal assignments that makes them so effective is that they are done more than once, providing students feedback so they can improve their performance (Flateby and Metzger, 2001). Third, these assignments can be extended with additional and/or more sophisticated questions that can require additional information gathering by students. Finally, the journal article information can be shared in a variety of peer teaching formats (Rubin and Hebert, 1998). They can provide students experience in using rubrics as they evaluate other students' journal assignments. Alternatively, journal article information can be used by students to collaboratively develop examination questions 
that involve multiple levels of thinking (Bloom, 1956).

While the final outcomes are highly positive most students still have difficulty at the beginning of skill development despite what appears to faculty as both clear instructions and well articulated expectations for outcomes. This leads us to our next lesson learned.

\section{Lesson 3: Expect Student Resistance and Consistently and Frequently Communicate the Rationale for what you do and High Expectations for Learning}

"Until you are willing to be confused about what you already know, what you know will never become wider, bigger or deeper."-Milton Erikson. As experienced learners, faculty generally embrace this credo. However, students, especially first year college students, don't necessarily feel the same way (Leamnson, 1999). To a majority of students, learning is solely the job of the instructor and should be straight forward information transfer. It is our experience that too many students fail to see the critical role they play in their own learning and are thus reluctant to take appropriate responsibility. In addition, the workload for a general education science course for nonscience majors is often seen as excessive and students do not expect a nonscience major's course to be as challenging. Our focus group analysis at USF has indicated that a significant portion of the students feel they do more work in STM than in their other classes and/or that STM is harder than their other classes. This result is supported by data from student surveys where typically $50-60 \%$ of students indicate that the course is more difficult than others. The resistance on the part of students to the active learning approach and workload issues was consistently expressed, as indicated below, in responses from STM instructors at several institutions and in focus group comments.

Example of instructor comments:

1. "The apathy demonstrated by many of the students was very frustrating."

2. "Text comprehension was difficult for the student. Resistance to a different teaching approach, this style was "too much work" for them. The students wanted the standard lecture-multiple choice exam format."
3. "Students need to be pushed to perform; they will not do their best if they don't have to."

4. "Students say, "This course requires more work than our other courses.",

Student focus group discussions and additional information from STM instructors suggest that much of the problem students have with the course level of difficulty seems to stem from the general lack of preparation (ACT, 2004). This seems especially true for the critical thinking/problem solving abilities that students say are not emphasized in high school science. Students fully expect to memorize for multiple choice exams. Thus they feel like the "game" is being changed in STM when written answers, problem solving/application and explanations are required. They often become frustrated when they don't perform well. This is despite vigorous and continued efforts to elaborate expectations, provide practice learning opportunities and to focus learning on a few targeted concepts that the students must apply to explain natural events. Student frustration can be reduced and improvements in performance can be achieved. However, as expectations with both their long- and short-term value are repeatedly emphasized, students are assisted in developing the necessary skills. This leads directly to Lesson 4.

\section{Lesson 4: Students Require Significant Guidance and Practice for Active Learning, Collaboration and Reflective Activities to be Effective}

"Smooth seas do not make skillful sailors."African Proverb. However, not many of us like to sail in rough seas. The intellectual challenge of this course for many students can be likened to the rough seas. This needs to be recognized and additional help provided students on how to do what is expected. While students may have engaged in group work, most have not mastered the skills required for successful group activities. The role of group work in learning and the responsibility and expectations of group members must be consistently expressed and positive results rewarded. We have found that assigning specific roles to students in the groups and then rotating these assignments is a good way to focus them on the various roles important for group success. It also typically improves the group product. This structure can be reduced or eliminated once students become accustomed to working in teams. Instructors can reinforce good group performance and 
assist groups in staying on task by being sure to interact with all groups during a session.

Rewards for group performance can be as simple as praise but must also include some grading of effective participation and of group work assignments. Assessing the latter two can be an effective way to promote quality group interactions and reduce the burden of grading while providing more rapid feedback to students through faster assignment turnaround. Alternatively, grading assignments in class can provide immediate feedback and can be an effective way to debrief an activity and help to ensure that important outcomes are clearly emphasized for students. Overwhelmingly, from semester to semester, student comments to instructors, focus group comments and surveys all indicate students enjoy and see benefits from group and/or collaborative learning.

\section{Lesson 5: Designing Flexibility into the Grading Process Accommodates Student Intellectual Development Over the Term and Enhances Student Satisfaction, Motivation and Effort}

"Treat people as if they were what they ought to be and you help them to become what they are capable of being."-Johann W. von Goethe. Grades are obviously important to students and, as indicated earlier, it takes time for students to adjust to the novel aspects of the course and to develop the skills necessary to be successful. This can lead to serious anxiety on the part of students who are used to getting A's in high school and are now perhaps receiving a $\mathrm{C}$ on an assignment or quiz. To overcome this, it is essential to communicate high expectations from the beginning. Let students know they are capable of this level of achievement and that you will assist them in achieving expectations through appropriate practice (NRC, 1997, 2001c). We find it necessary to continually emphasize the road to success is through preclass preparation and participation in class activities while focusing on the learning outcomes. Preparation is improved if students receive points/grades for preparation. Awarded points do not have to be many nor do they have to be given for all assignments. If you choose to randomly grade selected assignments, students need to know this ahead of time. In all cases it is important to consistently communicate that what students do for homework and in class is practice directly relevant to high performance on course tests.
Since we often see large improvements in student performance and intellectual development over time as students begin to master the new learning skills and abilities, we have found it important to have this reflected in their grades. Both motivation and performance are enhanced for many students when they understand a better grade is still possible as the semester progresses. Perhaps the most successful method to reward improvement has been to have assignments and tests count for progressively more during the course of the semester and/or to have a cumulative final that can be doubled by also counting it as a replacement of an earlier examination. Some faculty also find extra credit assignments useful, however, these require more grading and may not send the right message to students concerning the value of regular coursework.

\section{Lesson 6: Long-Term Support of Peers, Chairs, and Deans is Important for Successful Faculty Involvement and Requires Ongoing Communication of Outcomes and Value of the Effort}

"Think like a wise man but communicate in the language of the people"--William Butler Yeats. While faculty advocating change are not necessarily wiser than their peers, chair or dean, they may be "speaking in another language" when it comes to science education. Many science faculty are not well versed in the changes to science education underway in colleges and universities around the country, nor as to why change is needed. The National Research Council provides a strong "voice" respected by scientists and administrators. Publications, such as Science Teaching Reconsidered (NRC, 1997) and several newer publications concerning how people learn (NRC, 1999b), how to improve undergraduate science education (NRC, 2003) and how people learn in science (NRC, 2005) along with the alarming reports emphasizing the need for improved teacher preparation in science and mathematics (NRC, 2001a; USDOE, 2000), can all serve as valuable and persuasive documents supporting the need for change. Together these resources can help colleagues understand the problem, why they should care and what can be done. Relating these issues to your local conditions and institutional goals makes the changes more compelling, especially for administrators.

Since peers, chair and dean are all involved in evaluating faculty productivity and chairs and deans 
are involved in resource and time allocations, it is important that they all recognize the value of science education reform and appreciate the time, effort and scholarly aspects of implementing quality science education (NRC, 2003). Peer and chair support is again essential for sustainability since at some point other faculty will need to be involved in any new or redesigned courses. Keeping them informed of progress is a good way to promote both interest and support and requires evaluating reform efforts (see Lesson 8). Faculty at all sites implementing "Science That Matters" have had very strong support, especially from chairs and deans at each institution. The successes thus far would not have been possible without it.

\section{Lesson 7: Working Collaboratively with Teacher Preparation Program Administrators, Faculty and Advisors is Essential to Promoting More Effective Science for Preteachers}

"If a child can't learn the way we teach, maybe we should teach the way they learn."-Ignacio Estrada. Certainly faculty and administrators from colleges of education are very pleased with the new instructional approach taken in STM-like courses. The standards-based content and emphasis on classroom engagement and reflective practice models instruction that future teachers will use in their classrooms (NSTA, 2003; NRC, 2001a; USDOE, 2000). While there is typically no problem convincing educators of the value of the approach, there may be a problem of communication between academic units (e.g. College of Arts and Science and College of Education) with advisors and administrators critical to the process. Once education administrators and faculty have agreed to promote or, better, require the course for pre-elementary and middle school education majors course information must be provided to advisors in a way they can use it to promote the classes. It is essential that information is incorporated into the standard packets made available to pre-education majors as promotional materials (including websites). Since advisors and administrators can change, be sure to check on this material and visit advisors at least yearly. A wonderful example of the full integration of the pre-education program with new general educations courses in science and mathematics for education majors can be found at one of our partner institutions-Manatee Community College. They have made teacher preparation a primary goal and the Teacher Preparation Program has "Science that Matters" I \& II as prominent welladvertised components.

Faculty in the sciences contemplating or attempting change in science courses taken by preservice teachers have much to gain from increased interaction with their education colleagues. Their expertise in design, delivery and evaluation of instruction can be invaluable in developing or improving learning in science. Working with Education colleges also make science faculty more aware of the critical role they play in teacher preparation. From an institutional view point it is important to note that these types of collaborative approaches are now required for accreditation in teacher education programs. Thus, these collaborations can lead to both learning improvements for students and positive accreditation outcomes for the institution.

\section{Lesson 8: Evaluating Improves Your Program; Work with a Professional to Improve Your Evaluation}

"You can't improve what you don't measure"Anonymous. Finding out what your students know and think about the course are essential for the continuous course improvement process and we emphasize process. Evaluations take time, forethought and skill. This creates added challenges for faculty. First, the in-class time used for evaluation can reduce time for content. This is an ongoing concern when using active learning strategies since they generally require more time to engage a topic. Providing it is well designed, the information provided is invaluable in improving the opportunity for positive student learning outcomes. Second, the pre-evaluation planning and the time necessary to analyze and operate on the findings put added time demands on already over-extended faculty. Some of these time pressures can be reduced if assessments are embedded in the course and serve more than one purpose. For instance, some writing assignments can be used both to assess students content mastery while also serving as evidence of higher order thinking and/or intellectual development (Flateby and Metzger, 1999, 2000). A third challenge is the need to obtain student data at very specific time points during the semester or year. This increases the need for extensive preplanning and careful execution. If the necessary data is not obtained, it will be another semester or year before the opportunity comes again, if at all. A fourth challenge is one of skill in designing and executing effective 
assessments and evaluations. Faculty often lack specific training in this area and we strongly suggest seeking advice from and collaboration with evaluation professionals in your institution. With increased accountability for student learning at the university level, many colleges and universities have professionals that focus on institutional effectiveness. These professionals can be excellent resources to assist interested faculty in the development and execution of evaluations. Institutional effectiveness professionals can also help faculty frame the important questions in ways that are answerable. This allows faculty more opportunity to improve their teaching and to transform what is learned into scholarly presentations. Since teacher preparation is a high priority, funds can often be assigned for measuring outcomes related to these programs. Science education faculty and graduate students can also be excellent sources of help and expertise. An instructional question or outcome can often be an exciting source of thesis work that can improve the evaluation and cost little or nothing.

We have used a number of assessment devices (see evaluation approaches) that are used in our ongoing evaluation and improvement process guided by Dr. Teresa Flateby Director of USF's Office of Testing and Evaluation. While all assessments contribute to our understanding, the focus groups have been particularly useful in identifying the source of problems and/or uncovering unexpected issues and what is working well. For instance, in our questioning students about development of critical thinking it became apparent they did not really know what it was, thus prompting us to focus special attention on this problem the next semester. Likewise, when asked how the problem solving approaches learned in STM were useful in other classes, the general reply was that students' other classes did not need or use problem solving. It was also clear that many students equated problem solving only with solving math problems. While the uniqueness or perceived uniqueness and rigor of STM can be a problem in maintaining student enrollment in two semesters of sequenced STM courses, it points up the larger problem of the lack of coherence and rigor in too many of our general education/foundational courses in colleges and universities. These issues underscore the need to improve communication with others in your department and colleges to address these larger scale problems.

Since we have thus far been reasonably successful in assessing student attitudes, we are now focusing on a more systematic way to analyze for im- provements in content knowledge. Our experience fits with data from a recent report (ACT, 2004) suggesting a majority of students come to college with large deficits in science background knowledge despite having multiple science courses in high school. While we often see improvements in intellectual development and critical thinking, the final level of content mastery for many students in STM is often still below expectations. While these students may have made large individual gains in knowledge and understanding from the time they entered the course, the final score on a test does not indicate the overall improvement and thus not illuminate the full value of the instruction. To address this issue pre-post test formats are being developed at some sites for next fall as a way of examining the value added aspect of the courses and to aid in identifying instructional activities that lead to greatest improvement in content mastery (Nazario et al., 2002). Other partners are considering specifying content outcomes that must be mastered before a passing grade is assigned, with students allowed multiple opportunities to demonstrate mastery.

\section{SUMMARY}

The course sequence "Science that Matters" has a major positive impact on students' attitudes about science, their perception of the relevance of science to their lives, and their capacity for critical thinking. Students also have increased confidence in their ability to understand and apply major science concepts. However, many students resist the active learning format and are not prepared for, nor expect, the general rigor of the courses. This can result in students not achieving sufficient mastery of content material, an outcome especially pertinent for future teachers.

Teaching "Science that Matters" has had a profound positive affect on all past and present course instructors. The experience serves as an excellent professional development vehicle, helping faculty transition from lecture-only formats to more engaged science classrooms. Another valuable benefit for instructors is the power of this course to promote understanding across disciplines and increase interdisciplinary emphasis in teaching. It is important to note that engaged teaching requires considerable time and effort on the part of faculty. This, in turn, requires institutional support for maximum effectiveness and long-term sustainability. There can be no doubt, however, that student achievement gains warrant the investment. 
With willing hearts and skillful hands, the difficult is done at once, the impossible takes a little longer.- English proverb

Although it remains a challenge to implement and sustain even small improvements in science education, significant strides are being made across the country. With the many "willing hearts and skillful hands" now committed to this initiative, the goal of effective science education is definitely within reach.

\section{REFERENCES}

American Association for the Advancement of Science. (1993). Project 2061 Benchmarks for Science Literacy, Oxford Press.

ACT Crisis at the Core: Preparing All Students for College and Work. (2004). ACT Inc. http://www.act.org/path/policy/pdf/ crisis_report.pdf (Accessed January 2005).

Assessment Resource Center: Institute for Research and Assessment in Higher Education University of Maryland, University College http://www.umuc.edu/distance/odell/ irahe/arc/6too.html (accessed January, 2005).

Bloom, B. S. (Ed.). (1956). Taxonomy of Educational Objectives: The Classification of Educational Goals: Handbook I, Cognitive Domain, New York, Longmans, Toronto.

Boyer Commission on Educating Undergraduates in the Research University (1998). Reinventing Undergraduate Education: A Blueprint for America's Research, Universities. Stony Brook, State University of New York at Stony Brook, NY.

BSCS Science T.R.A.C.S. (1999). Teacher's How-To-Handbook Strategies and Methods Across the Curriculum, Kendall/Hunt pub.

Designed Instruction. (2003). Modeling for Student Learning: A Translational Meta-Analysis of Scientifically Based Education Research Evidence, Designed Instruction. Inc.

Druger, M. (2002). It all depends: A perspective on science teaching at all levels. Journal of College Science Teaching 31: 493494.

Druit, R., and Treagust, D. F. (2003). Conceptual change; a powerful framework for improving science teaching and learning. International Journal of Science Education 25: 671- 688.

Flateby, T. L., and Metzger, E. (1999). Writing Assessment Instrument for Higher Order Thinking Skills, Assessment Update, March-April, pp. 6-7.

Flateby, T. L., and Metzger, E. (2000). Cognitive Level and Quality of Writing Assessment: A Training Manual, USF Publishing, Tampa, FL.

Flateby, T. L., and Metzger, E. (2001). Instructional Implications of the Cognitive Level and Quality of Writing Assessment (CLAQWA), Assessment Update, January-February, pp. 411.

Grasha, A. F. (1996). Teaching with Style: A Practical Guide to Enhancing Learning by Understanding Teaching and Learning Styles, Pittsburg, Alliance Publishers, PA.

Griffin, M. (1995). You can't get there from here: Situated learning, transfer, and map skills. Contemporary Educational Psychology 20: 65-87.

Grosslight, L., Unger, C., Jay, E., and Smith, C. L. (1991). Understanding models and their use in science: Conceptions of middle and high school students and experts. Journal of Research in Science Teaching 28: 799-822.

Holloway, J. H. (2003). Research link/student teamwork. Education Leadership 61: 91-92.

Klionsky, D. J. (2003). Why the scientific method matters: A cautionary tale. Teach. Prof. 17: 4.
Kolb, D. A. (1984). Experiential Learning: Experience as a Source of Learning and Development, Englewood Cliffs, Prentice Hall, NJ.

Leamnson, R. (1999). Thinking about teaching and learning developing habits of mind with first year in college students. Stylus, Sterling VI: $1-165$.

Leamnson, R. (2000). Learning as biological brain change. Change 32: $34-40$.

Marbach-Ad, G., and Sokolove, P. G. (2000). Good Science Begins with Good Questions. Journal of College Science Teaching 30: 192-195.

National Research Council. (1996). National Science Education Standards, National Academy Press, Washington, DC.

National Research Council. (1997). Science Teaching Reconsidered: A Handbook, National Academy Press, Washington DC, pp. 1-87.

National Research Council. (1999a). Transforming Undergraduate Education in Science, Mathematics, Engineering and Technology, Available on line through National Academy Press.

National Research Council. (1999b). How People Learn: Bridging Research and Practice, Brain, Mind, Experience and School, The National Academies Press, Washington, DC.

National Research Council. (2001a). Educating Teachers of Science, Mathematics, and Technology: New Practices for the New Millennium, National Academy Press, Washington, DC.

National Research Council. (2001b). Knowing What Students Know: The Science and Design of Educational Assessment, National Academy Press, Washington, DC.

National Research Council. (2001c). Classroom Assessment and the National Science Education Standards, National Academy Press, Washington, DC

National Research Council. (2003). Evaluating and Improving Undergraduate Teaching in Science, Technology, Engineering, and Mathematics, The National Academies Press, Washington, DC.

National Research Council. (2005). How Students Learn: History, Mathematics, and Science in the Classroom: Board on Behavioral, Cognitive, and Sensory Sciences and Education, National Academy Press, Washington, DC.

National Science Teachers Association. (2003). Standards for Science Teacher Preparation.

Nazario, G. M., Burrowes, P. A., and Rodrigues, J. (2002). Persisting misconceptions: Using pre-and post tests to identify biological misconceptions. Journal of College Science Teaching 31: 292-295.

On Line Evaluation Resource (OLER) supported by the National Science Foundation http://oerl.sri.com/ (accessed January, 2005).

Palady, L. (2002). Science for citizens: Brand new century, same old dilemma. Journal of College Science Teaching 31: 422-423.

Penick, J. E., Crow, L. W., and Bonnstetter, R. J. (1996). Questions are the answer. The Science Teacher, January 27-29.

Rubin, L., and Hebert, C. (1998). Model for active learning: Collaborative peer teaching. College Teaching 46: 2631.

Sarasin, L. C. (1998). Learning Style Perspectives: Impact in the Classroom Madison, WI Atwood Publishing.

Strong, R., Silver, H., Perini, M., and Tuculescu, G. (2003). Boredom and its opposite an understanding of natural human interests gives teachers tools for overcoming students' reluctance to learn. Education Leadership 61: 24-29.

Tanner, K. D., Chatman, E. S., and Allen, D. E. (2003). Cooperative learning in the science classroom: Beyond students working in groups. Cell Biol. Educ. 2: 1-5.

USDOE -Glenn Commission. (2000). Before It's Too Late: A Report to the Nation from The National Commission on Mathematics and Science Teaching for the 21st Century, Jessup, US Department of Education, Education Publication Center, MD. 